\title{
Governing the gold rush into emerging markets: a case study of Indonesia's regulatory responses to the expansion of Chinese-backed online P2P lending
}

\author{
Angela Tritto ${ }^{1 *}$ (D, Yujia $\mathrm{He}^{1,2}$ and Victoria Amanda Junaedi ${ }^{3}$
}

\author{
* Correspondence: tritto@ust.hk \\ ${ }^{1}$ Institute for Emerging Market \\ Studies, The Hong Kong University \\ of Science and Technology, Lo Ka \\ Chung Building, Clear Water Bay, \\ Kowloon, Hong Kong SAR, China \\ Full list of author information is \\ available at the end of the article
}

\begin{abstract}
Peer-to-peer (P2P) lending has the potential to boost financial inclusion in emerging markets. This paper contributes to the literature on fintech governance in emerging Asian markets. It examines the case of the Indonesian government's approach in regulating the $\mathrm{P} 2 \mathrm{P}$ lending sector using both primary interviews and secondary firmlevel data. Driven by regulation tightening in China and regulatory gaps in Indonesia, Chinese investments became the largest in this sector contributing, however, to growing risks from illegal business practices. The Indonesian government responded by creating new regulations and institutions, mitigating risks without stifling the potential for financial inclusion. We conclude a proactive approach towards monitoring and regulating emerging high-tech industries should be sought by strengthening links with industry and civil society, and through international cooperation for policy and knowledge sharing.
\end{abstract}

Keywords: Fintech, P2P, Internet finance, Governance, Emerging market

\section{Introduction}

Peer-to-peer lending (also known as P2P lending, or platform lending) is a relatively new form of online lending that matches potential borrowers with investors using digital and communications technologies. Since the world's first online P2P lending platform, Zopa, started in the United Kingdom in 2005, platforms have sprung up around the world. The global P2P lending market was valued at US\$26 billion in 2015 and is projected to reach US $\$ 460$ billion by 2022, growing at an annual rate of $51.5 \%$ (Research and Markets 2017). This growth is propelled by not just developed economies, such as the United States and Europe, but to an increasing extent by emerging markets. While formal borrowing is the most common source of credit in high-income economies (almost 90\% of borrowers employed financial institutions or credit cards in 2017), borrowing from family and friends is most common in developing economies (World Bank 2017a). Besides, emerging markets face significant financing gaps for MSMEs (Micro, Small and Medium Enterprises). The gap of the East Asia and Pacific

(c) The Author(s). 2020 Open Access This article is licensed under a Creative Commons Attribution 4.0 International License, which permits use, sharing, adaptation, distribution and reproduction in any medium or format, as long as you give appropriate credit to the original author(s) and the source, provide a link to the Creative Commons licence, and indicate if changes were made. The images or other third party material in this article are included in the article's Creative Commons licence, unless indicated otherwise in a credit line to the material. If material is not included in the article's Creative Commons licence and your intended use is not permitted by statutory regulation or exceeds the permitted use, you will need to obtain permission directly from the copyright holder. To view a copy of this licence, visit http://creativecommons.org/licenses/by/4.0/. 
region accounts to USD 2.4 billion, representing 54\% of the global MSME figure (World Bank 2017b). The increasing convergence of banking and mobile services in emerging markets is not only allowing banks to get around the constraints of traditional brick-and-mortar outlets, but also enabling technology leapfrogging to reach these under-banked groups (Amankwah-Amoah 2019).

Asia and, particularly, Southeast Asia represent some of the most promising markets for online lending because of four main reasons: the large and young population, the high Internet penetration and smartphone usage, the growing spending market, and the largely unbanked population. Indonesia is the perfect example. According to the Indonesian Financial Services Authority (or OJK, Otoritas Jasa Keuangan), by December 2018, the loans disbursed from registered lenders had totaled over 22.66 trillion IDR (1.58 billion USD ${ }^{1}$ ) (OJK 2018a). However, P2P lending also poses a rising challenge for emerging-market regulators. The case of Indonesia provides a useful example to examine the effect of foreign investments from other countries such as China on the domestic regulatory environment. Unless they have already done so, policymakers in Southeast Asia's emerging economies and beyond will need to follow with regulations and institutional responses, as they will find themselves dealing with similar issues to China and Indonesia. Particularly, the Chinese and Indonesian cases highlight the pitfalls of a reactive regulation approach. Through proactive regulatory approaches, other emerging markets can drive the online lending industries towards areas of needs, as in the case of Malaysia allowing P2P lending only for MSMEs, or promote better investments, as in the case of Chinese companies eyeing acquisitions in the credit-starved but already developed Indian market (Jao 2019).

This paper examines Indonesia's innovative and prompt regulatory and institutional responses to the expansion of online P2P lending backed by foreign investments predominantly from China using both primary interviews and secondary firm-level data. It starts by analyzing the P2P lending expansion in China, the resultant risks, and recent regulation efforts. It then analyzes the development of the P2P lending sector in Indonesia, the entry of Chinese capital, and the Indonesian government's response resulting in policy and institutional changes in P2P lending governance. The paper argues that the Indonesian approach to regulation is to mitigate risks from market expansion powered by foreign capital (primarily from China) without stifling innovation's potential to boost financial inclusion. To do so, the state has imposed regulatory and institutional changes to promote synergy with market players and industry selfregulation. The study concludes with policy recommendations and directions for future research.

\section{Literature review}

The growing convergence of information technology and financial services in the developing world has led to new research on the fast-moving development of financial technologies such as online lending. Scholars have focused on the interplay of financial products and services, technologies, risks, and institutions, and how they shape outcomes such as financial inclusion and poverty reduction in various national contexts

$\overline{{ }^{1} 1 \text { USD }=14,363.07 \text { IDR (May 2019) }}$ 
(Shen, 2015; Buckley \& Webster, 2016; Stern et al. 2017; Tsai 2017; Claessens et al. 2018; Malady et al. 2018; Bateman et al. 2019; Clarke 2019; Singh 2019; Suryono et al. 2019; Lai and Samers 2020; Ehrentraud et al. 2020; Thakor 2020; Wang et al. 2020). Recent reports also examined the potential outcomes of a larger share of fintech-facilitated credit in the economy, finding that while it could increase financial stability by providing access to alternative funding sources and creating efficiency pressures on incumbent banks, it might also weaken lending standards and introduce more procyclical credit provision in the economy (FSB 2017). The rapid fintech growth in China and Southeast Asia led to new research examining domestic regulatory regimes and challenges in these markets and the roles of government regulations through either a single-country or a comparative lens (Shim and Shin 2016; Davis et al. 2017; Loubere 2017; Gruin and Knaack 2019; Yang et al. 2018; Huang 2018; Wang 2018a; Wang 2018b; Xu et al. 2019; Yu and Shen 2019; You 2017; Shaydullina 2018). For instance, Iwasaki's study (2018) examines the emergence of fintech firms in Southeast Asia. It analyzes activities such as mobile payments, money transfers, and online lending as solutions to solve existing problems in finance, and the regulatory schemes to manage risks and economic growth. Iman (2018) examines fintech development in Indonesia through expert interviews and argues that regulatory immaturity potentially exposes users to fraud. Pulse Lab Jakarta's study (2018) takes a design-thinking approach and interviews micro enterprises who are either agents or users of fintech, and finds that while high-level policymaking can boost financial inclusion, design principles that address the mental barriers and enabling factors for fintech adoption are vital for the micro enterprises to actively use and benefit from fintech. PwC's study (2019) on Indonesia's unique fintech lending ecosystem finds that the target market for fintech lending includes both underserved individuals and MSMEs with limited physical and data access. Its principle-based and collaborative regulatory approach aims to control the market and minimize unethical practices while enabling the ecosystem to grow.

Existing literature has also analyzed the financial technologies as "disruptive innovation" (Palmié et al. 2020) and new mechanisms by governments, institutions and firms to adapt to rapid technological change. For instance, research has examined the phases of development of the industry, and the legal, financial, and institutional designs required to spur innovation by balancing competition and collaboration, with the responsibility to mitigate risks for consumers, investors, and the financial system from technology development (Pei 2018; Palmié et al. 2020). A major focus in new government policy mechanisms is the regulatory sandbox approach, launched in the United Kingdom in 2016 and subsequently emulated by numerous other countries. The regulatory sandbox is "a framework set up by a financial sector regulator to allow small-scale, live testing of innovations by private firms in a controlled environment (operating under a special exemption, allowance, or other limited, time-bound exception) under the regulator's supervision" (Jenik and Lauer 2017). Davis et al. (2017) explain that Indonesia's legal and regulatory measures, especially the regulatory sandbox to regulate online P2P lending, follow a pragmatic approach that is close to international best practices to help grow the sector and enable SME financing. They argue that, compared with advanced economies, Indonesian regulations have stronger education and national-interest focus and weaker consumer protection.

Other scholars have focused on specific challenges in P2P lending in Indonesia, including consumer protection, legality of the apps, interest rates, debt collection, and 
loan default. For instance, Pranata and Farandy (2019) proposed a big-data-based risk surveillance system for P2P lending based on platforms' reviews on Google Play. They found that OJK had not authorized most of the apps, and these illegal apps on average had worse review ratings than authorized apps. In addition, they found many negative reviews related to unethical debt collection and excessive interest rates, recommending special supervision by OJK for risky platforms. Santoso et al. (2019) found that specific characteristics of loans and borrowers could explain differences in interest rate and loan default status, and recommended more extensive information disclosure by platforms and stronger platform supervision by OJK with mandatory reporting to decrease information asymmetry and lower the cost of borrowing.

This paper contributes to the existing literature in two ways. Firstly, existing fintech literature tends to conceptualize and analyze regulatory changes in a country by tracing domestic market expansion along with the economic and social impacts that warrant enhanced regulation, or domestic stakeholder actions, or networks that drive policy changes (Shim and Shin 2016; Davis et al. 2017; Claessens et al. 2018; Wang 2018a; Palmié et al. 2020). What has garnered less attention is the broader picture of fintech as a global industry powered by transnational capital flows and the role of foreign business practices and investments in influencing the domestic environment, triggering governance responses. Often, technologies in emerging markets are imported from developed economies or large and technologically advanced emerging markets like China. As this paper shows, the movement of foreign capital into under-regulated markets can lead to new business practices, and to economic and social impacts that prompt changes into existing regulatory and institutional frameworks. Our empirical findings provide important evidence to understand the impact of foreign investments on fintech industry development and the governance mechanisms to manage the growth pains of the industry in an emerging market. Secondly, this study contributes empirically and methodologically to the small body of research on online lending and fintech governance in Southeast Asia. Our analysis employs data from primary interviews, as well as secondary firm-level data of OJK-registered online lending platforms, with aggregated information on investor relations and loan product types from numerous sources. To our knowledge, this is the first scholarly analysis of this recent phenomenon drawing on both primary and secondary data.

On a broader theoretical level, our study also contributes to the discussion on the role of the Asian state in economic governance, specifically in relation to recent scholarship on the developmental state (Johnson 1982). This model initially focused on East Asia's development miracle in the 1980s, to the "plan-rational state" and its autonomous economic bureaucracy favoring resource allocation in its target industries. Scholars emphasized the importance of the state's interaction with the market and society while maintaining its capacity to achieve development goals (Wade 1990; Weiss 1998). More recent scholarship has moved even further and argued that the developmentally oriented states need to adapt to globalized trade and domestic socioeconomic transition. The government's role in developing Asia has reoriented towards policy creation and coordination to sustain growth within the global regimes of production, with increased delegation of certain responsibilities to business and professional self-regulation, and to civil society (Braithwaite 2008; Jarvis 2012; Jayasuriya 2001; Carroll and Jarvis 2017). In the context of technological and sustainability transitions in 
Southeast Asia, scholars found that "capitalist developmental states in East and Southeast Asia have been better able to harness global economic forces through an openness to trade and investment and effective public-private institutions" (Rock et al. 2009, p. 14). Our findings concur with such analysis, as Indonesia's fintech governance approach seeks to promote domestic industry expansion and mitigate risks associated with the global flow of capital and technology by actively building industry linkages and professional self-regulatory institutions.

\section{Methodology}

The research employs a case study methodology, which allows the investigator to understand complex phenomena retaining "the holistic and meaningful characteristics of real-life events" (Yin 2003). We rely on a mix of secondary data and primary interview data. The twenty-five in-depth interviews with experts were collected through a snowball sampling method starting from contacts in fintech startup firms, foreign investment agencies, consulting and banking firms. Table 1 summarizes the details of such interviews with the corresponding interview code.

The interviews were conducted both in person, during two visits to Jakarta in August 2018 and in July-August 2019, and over the phone in early 2019. Interviews were semistructured, generally divided into three parts: background of the P2P lending market in Indonesia, policies related to P2P lending, an overview of their company or association. Some interviews were conducted and recorded in Bahasa Indonesia or Chinese, and later translated into English. We performed a pattern thematic analysis by grouping interview data under themes such as industry background, practices, governance. This process allowed us to perform triangulations across different interviews and with the quantitative data.

Information on fintech and its relevant policies in China and Indonesia was gathered from official government documents and translated into English when necessary. Given the limitation of the scholarly and legal literature on the fintech space in Indonesia, we have also obtained secondary data from industry sources, news reports, and press releases.

For our data analysis on firm-level investments and products, we collected a list of registered online P2P companies from OJK's website. As of December 2018, OJK had released a list of 88 registered entities (OJK 2019), containing information such as the platform's name, website URL, the name of the registered company, the registration number, the registration date, funding information, and lending products. We obtained ownership information mainly from the platform's website and press releases, and obtained startup funding information from Crunchbase.com. We also collected information from other relevant sources, such as LinkedIn company pages. Information about the firm leadership and the language requirements in job postings allowed us to deduce the platform's possible ties to foreign investment. For instance, a recently established platform with a Chinese CEO may originate from China. We consider a start-up that has received funding from Chinese venture capital to have ties to Chinese investment, and similarly so for other countries. Information on the types of loan products was collected from the respective platform's websites and subsequently categorized into short-term loans and non-short-term loans. We also divided the product types by the primary target markets, namely MSME or corporations, consumer or individuals, Sharia loans, education funds, health funds, agriculture funds, maritime funds, real estate funds, e-commerce financing, and women- 
Table 1 Table of Interviewee Characteristics

\begin{tabular}{|c|c|c|c|c|c|}
\hline No. & Organization & Role & Time & Mode & Location \\
\hline 1 & P2P platform & CEO & $1 / 2019$ & \multicolumn{2}{|c|}{ Over the phone } \\
\hline 2 & $\begin{array}{l}\text { Asosiasi Fintech Pendanaan } \\
\text { Bersama Indonesia } \\
\text { (or AFPI, the Indonesian Fintech } \\
\text { Lending Association) } \\
\text { P2P platform }\end{array}$ & $\begin{array}{l}\text { Vice-Chairman, } \\
\text { CEO and founder }\end{array}$ & $2 / 2019$ & \multicolumn{2}{|c|}{ Over the phone } \\
\hline 3 & Bank & Head of Investment team & $9 / 2019$ & \multicolumn{2}{|c|}{ Over the phone } \\
\hline 4 & International consulting firm & Head of China desk & $7 / 2018$ & In person & Jakarta \\
\hline 5 & Chamber of Commerce & Chief Representative & $8 / 2018$ & In person & Jakarta \\
\hline 6 & Indonesian Institute of Sciences & Researcher & $5 / 2019$ & \multicolumn{2}{|c|}{ Over the phone } \\
\hline 7 & $\begin{array}{l}\text { AFPI } \\
\text { P2P platform }\end{array}$ & $\begin{array}{l}\text { Vice Chairman } \\
\text { CEO and founder }\end{array}$ & $7 / 2019$ & In person & Jakarta \\
\hline 8 & Welab & Head & $7 / 2019$ & In person & Jakarta \\
\hline 9 & Law firm & Associate & $7 / 2019$ & in person & Jakarta \\
\hline 10 & Government research institute & Researcher & $7 / 2019$ & In person & Jakarta \\
\hline 11 & Chamber of Commerce & Chief Representative & $7 / 2019$ & In person & Jakarta \\
\hline 12 & P2P platform & Co-founders & $7 / 2019$ & In person & Jakarta \\
\hline 13 & P2P platform & CEO & $7 / 2019$ & In person & Jakarta \\
\hline 14 & Insurance company & Director & $7 / 2019$ & In person & Jakarta \\
\hline 15 & International consulting firm & Senior Associate & $7 / 2019$ & In person & Jakarta \\
\hline 16 & Research institute & Senior economist & $7 / 2019$ & In person & Jakarta \\
\hline 17 & Research institute & $\begin{array}{l}\text { Partnership Officer, Policy Engagement } \\
\text { Officer }\end{array}$ & $7 / 2019$ & In person & Jakarta \\
\hline 18 & Logistic company & Research Head & $7 / 2019$ & In person & Jakarta \\
\hline 19 & $\begin{array}{l}\text { P2P platform / P2P } \\
\text { association }\end{array}$ & CEO / Head of consumer lending & $7 / 2019$ & In person & Jakarta \\
\hline 20 & Law firm & Deputy Managing Partner & $7 / 2019$ & In person & Jakarta \\
\hline 21 & Logistic company & $\begin{array}{l}\text { Head of Business } \\
\text { Development }\end{array}$ & $7 / 2019$ & In person & Jakarta \\
\hline 22 & Insurance company & Vice Head & $7 / 2019$ & In person & Jakarta \\
\hline 23 & $\begin{array}{l}\text { Consumer protection } \\
\text { association }\end{array}$ & Head & $7 / 2019$ & In person & Jakarta \\
\hline 24 & $\begin{array}{l}\text { Government Investment } \\
\text { Coordination Board }\end{array}$ & Head of China desk & $7 / 2019$ & In person & Jakarta \\
\hline 25 & Venture Capital firm & Founder & $8 / 2019$ & In person & Singapore \\
\hline
\end{tabular}

specific financing. Some newly registered companies did not have any information on their investor relations and product types, so we classified them as not having enough information.

\section{China's rise in online lending}

China has become a major fintech market power. In online lending, China is the world's largest market in terms of accumulated loan disbursed (Morgan Stanley Research 2015). The first Chinese online lending platform, PPDAI Group, was launched in 2007 (Liu 2018a, 2018b). By July 2017, there were 5029 P2P platforms with over 1.09 trillion RMB (163 billion USD) in outstanding loans (Tsai 2017). China also has the world's highest adoption rate of fintech services. According to a survey, $69 \%$ of the 
Chinese population has used fintech services, and $46 \%$ has used online borrowing (EY 2017). Fintech companies such as Alibaba's Ant Financial, the world's highest-valued "unicorn" (private companies with valuations above USD 1 billion) are leading innovators. According to a Cambridge University survey, approximately $15 \%$ of the budget of major Chinese P2P platforms went towards research and development (R\&D) initiatives in areas such as automation (Cambridge Center for Alternative Finance 2018).

Several factors have facilitated the rise of online lending in China (Huang 2018). Firstly, China has a vast Internet user base, with 904 million Internet users as of March 2020, accounting for $64.6 \%$ of the total population (CNNIC 2020), and its Internet penetration rate is still growing. Secondly, the traditional banking system favors stateowned enterprises, and does not offer easy access to finance for MSMEs and private households. In 2017, China faced an MSMEs financing gap of 1.89 trillion USD, and only $22.7 \%$ of Chinese aged over 15 accessed credit through formal borrowing (World Bank 2017a; World Bank 2017b). Thirdly, online lending offers much higher interest rates than traditional bank deposits, whose rates are under the control of the People's Bank of China (PBOC), providing investors with an attractive alternative. As an example, the average interest rate for a five-year certificate of deposit (CD), the deposit product with the highest rate at most banks, was 3.445\% in 2018 (Zhuo 2019). In comparison, according to data on the website of Wangdaizhijia (https://shuju.wdzj.com/), a P2P research portal, investments in online lending platforms in 2018 had an anticipated yearly average return between $9.58 \%$ and $10.3 \%$. In the words of an industry expert, "investors keep going back to P2P because there are no other alternative investments ready for them" (Feng 2018).

However, the online lending boom with little regulatory oversight generated significant financial risks. Before 2015, P2P lending platforms in China operated in a regulatory vacuum: they only had to register with the local administration of industry and commerce, with no minimum market entry requirements, no industry standards, and no regulators overseeing the sector (Zhang and Pan 2016). By the end of 2015, 1031 online P2P platforms were marked as "in trouble," out of 3448 platforms in operation. These "in-trouble" platforms had cash shortage in paying off investors, run-away owners leaving without settling outstanding debts, or were under investigation for economic crimes (Liu 2018a). One example is Ezubao, one of the largest P2P lending platforms, which collapsed in 2015. Its employees were charged for effectively creating a Ponzi scheme using fake lending projects, failing to repay as much as 38 billion RMB to investors (Feng 2018). The situation turned political, as investors losing their savings traveled to protest in front of regulatory agencies in Beijing and other provincial capitals, prompting local governments to censor what they viewed as social instability (Li et al 2018).

Social discontent involving loan sharking, identity theft, consumer privacy violations, and misleading marketing were also abundant. For instance, some Chinese P2P platforms monitored the borrowers' smartphone use without permission, and collected data such as phone contact lists, call logs, and location services to track defaulting borrowers and harass their family and friends. Security breaches that enabled the stealing of user information were also on the rise (Stevenson and Li 2017). The Chinese government has banned the approval of credit cards for students under the age of eighteen since 2009 and required adult college students to have written permission from 
guardians to apply for credit cards. Sensing this potential underserved market, online platforms also employed unethical measures to aggressively target young borrowers for whom obtaining commercial loans was difficult. Online lenders on Jiedaibao, a P2P platform, targeted female college student borrowers and demanded "naked loans" nude photos and videos as collateral to be eligible for higher loan amounts. Lenders threatened to publish the photos online if the payments were not on time (Leavenworth 2016). The naked photos and videos of over 100 women were leaked online later (AFP 2016). State media also reported suicides of students linked to excessive online borrowing (Zhang and Pan 2016). As a result, in 2016 the Ministry of Education issued a statement with the China Banking Regulatory Commission (CBRC) demanding closer scrutiny of lending advertising and credit evaluation targeting students (PRC Ministry of Education and China Banking and Insurance Regulatory Commission 2016).

Facing growing market and social pressures, the Chinese government started regulating online lending ( $\mathrm{Xu}$ et al. 2019). The Guiding Opinions on Promoting the Sound Development of Internet Finance, released in 2015, defined the P2P platforms' roles strictly as information intermediaries, with no ability to provide credit enhancement, concentrate funds, or raise funds illegally (PBOC et al. 2015). The Supreme Court of China stipulated legal rules about private online lending in 2015, such as loan interest (payments with rate below $24 \%$ are protected by law, between $24 \%$ and $36 \%$ are voluntary responsibilities of borrowers, exceeding 36\% are illegal) (Supreme People's Court of China 2015). Central regulators jointly released an interim directive on P2P lending in 2016 (CBRC et al. 2016), including clauses on registration, loan requirements, marketing, information privacy and security, consumer protection, and anti-moneylaundering measures. Subsequently, a series of policies formed a more comprehensive regulatory framework imposing stricter rules on platform registration (CBRC 2016b), fund management and deposit with an approved custodian bank (CBRC 2017a), and information disclosure and management (CBRC 2017b). In 2016, CBRC, the main financial regulator, also waged a special national campaign jointly with other central agencies, local governments, and police forces to curb online lending risks and eliminate illegal practices (CBRC 2016a). Platforms needed to obtain three documents by the end of 2018 to avoid being shut down by regulators: the ICP (Internet Content Provider) license, the National Information System Security Protection Level 3 Certificate, and the Custodian Bank's approval on a government-approved whitelist (Liu 2018b).

Regulators also worked with industry players to create new self-regulating industry associations to guide compliance. In 2016, PBOC, in collaboration with CBRC, CSRC (China Securities Regulatory Commission), and CIRC (China Insurance Regulatory Commission) created the National Internet Finance Association of China (NIFA) to support governance efforts. NIFA had more than 400 initial corporate members, including 19 online lending platforms. Similar local-level internet finance associations have also sprung up in major cities across the country to promote industry development and regulatory compliance. For instance, since February 2019, the Beijing Internet Finance Association has been working with online lenders registered in Beijing to protect investors from runaway debt, through the public release of a list of companies and individuals with unpaid debts due on online platforms (People's Daily 2019).

As a result, the industry has been going through a significant correction. As Fig. 1 shows, net new investments into Chinese online lending platforms have fluctuated with 


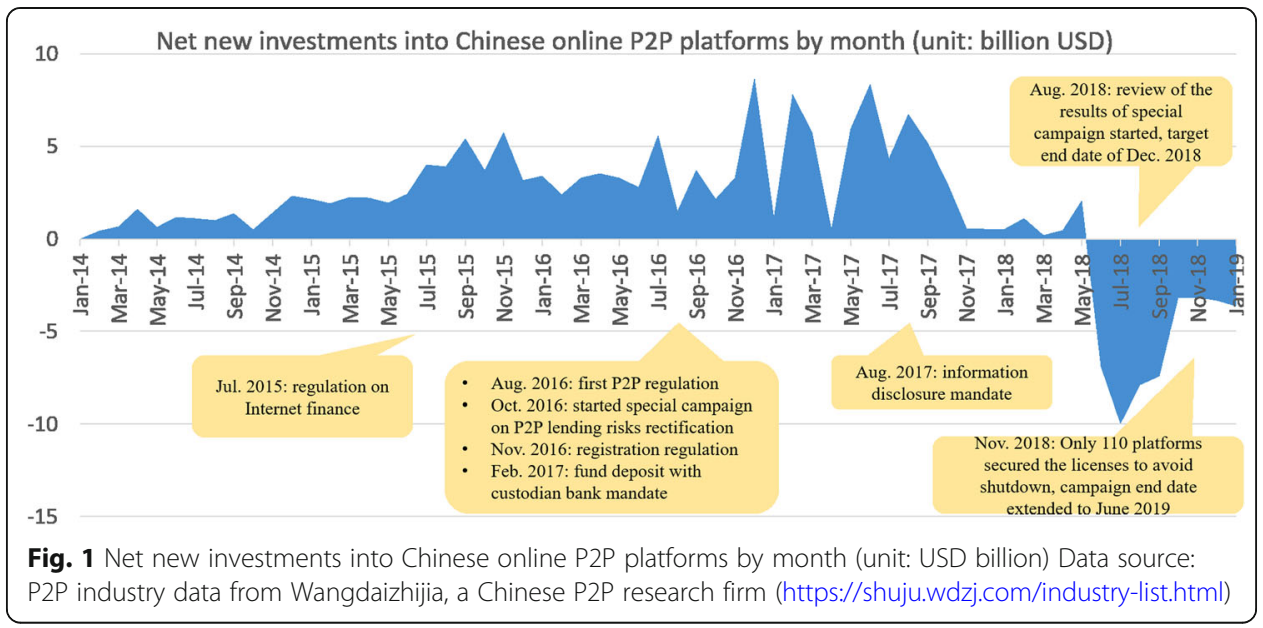

increased regulatory stringency and have turned negative since mid-2018. In June 2018, the head of CBRC issued a public warning that investors betting on risky platforms should be "prepared to lose the entire amount of their principal for any investment with an estimated return of more than 10 percent" (Jiang 2018). CBRC started the review process for platforms in August 2018. By November 2018, the number of online lending platforms had dropped from the peak of 3448 platforms in 2015 to merely 1181 . Only 110 platforms, less than $10 \%$ of those in operation, secured the three licenses by 2018 (Liu 2018a, 2018b). The special campaign was extended to June 2019 to allow more time for existing platforms to correct noncompliant behavior and obtain licenses (Xu et al. 2019). Further, in November 2019, a notice issued by China's Internet Financial Risk Special Rectification Work Leadership Team Office demanded that all existing P2P firms clear outstanding debt in two years and transition to become online small loan providers (Reuters 2019). Online small loan providers would have to rely on funding from institutions and cannot grow their business using investment from small investors, and need to have the minimum registered capital of 50 million RMB to receive provincial-level license or 1 billion RMB to receive nationwide license (Lee 2020). The policy has effectively mandated the exit of non-institutional investors as well as smaller and less-established firms from the industry.

Facing a stricter environment at home, Chinese investors and platform developers have expanded to untapped emerging markets. The geographical proximity between China and Southeast Asia, existing business relationships among local Chinese communities, along with the large unbanked population make Southeast Asia a desirable destination for overseas expansion. The lightly regulated Indonesian market, when compared to the tightening regulatory oversight in China, coupled with an open approach by the government to develop the industry, attracted online Chinese lenders to unlock new opportunities following the next gold rush (Interview8; Interview11; Interview13).

\section{The gold rush into Indonesia}

P2P lending has enormous potential in Indonesia. With a population exceeding 260 million, Indonesia is the world's fourth most populous country and Southeast Asia's 
largest digital market. In 2017, the country had 143.3 million active internet users, 124.8 million mobile phone users, and a booming e-commerce sector with $20 \%$ Yearon-Year (Y-o-Y) growth (Internetworldstats 2018; Hootsuite 2018). However, as of 2017 , only $49 \%$ of the population had a bank account, and merely $2 \%$ owned credit cards (World Bank 2017a). Systemic issues in financial services administration, low financial literacy, and poor access to market have rendered it difficult for brick-andmortar banks to reach the underbanked (Iwasaki 2018). This financing gap also pertains to MSMEs (Micro, Small and Medium Enterprises), which despite contributing to 60\% of the nation's GDP experienced a 166 billion USD financing gap in 2017 (World Bank 2017b). As a result, P2P lending platforms in Indonesia have boomed in the past few years attracting both domestic and foreign investors.

Foreign investors in Indonesia's online lending sector come from diverse origins (e.g., China, Europe, Singapore, USA). Amongst the first to enter Indonesia were Eastern European companies (Interview1), but since 2016 Chinese companies have become the dominant and most active group. The Vice President of Asosiasi Fintech Pendanaan Bersama Indonesia (or AFPI, the Indonesian Fintech Lending Association) outlined three main reasons for this. Firstly, the recent policy in China that regulated the industry made some people who "had lost their piece of the pie" look for (market) substitutes. Indonesia was one of the possible and attractive alternatives. Secondly, Chinese players have the technological capability to build lending platforms. Finally, some of these platforms also have substantial financial resources (Interview2). Several interviewees confirmed these reasons (Interview6; Interview8; Interview11; Interview23; Interview25). Most of the Chinese players entered the market providing short-term consumer loans (Interview1). Such loans usually carry a much higher interest rate with a shorter loan period (i.e., less than 30 days), with a quick loan turnaround (usually in a few minutes to a few hours) (Kagan 2018).

\section{The role of Chinese capital} Investor origin

As of December 2018, OJK had released a list of 88 registered online lending firms in Indonesia. From our findings and analysis of the directory, we found details of funding or ownership information in 47 companies (see Table 2). The other 41 firms were new corporations without available information or companies with little or no disclosed information online. Out of the 47 companies, we found that at least 18 firms (38\%) had Chinese shareholders (see Fig. 2). The second and third most common foreign funding sources were other Southeast Asian countries (15 firms) and Japan (9 firms). Additionally, we found investments from the United States (9 firms), Europe (including United Kingdom, 3 firms), and other countries (4 firms). These are not mutually exclusive, as many firms received funding from multiple foreign investors. Our findings are in line with our interview data, which have shown that most foreign players at the time came from mainland China. Chinese investors "often set up shell companies in Hong Kong and Singapore to bypass Beijing's strict controls over cross-border money flows and hire proxy agents as local partners" (Interview19; Interview25; Potkin et al. 2018). Hence, the actual proportion of firms with Chinese investments could have been higher. 
Table 2 Summary of possible investors out of 47 registered P2P lending firms

\begin{tabular}{lll}
\hline Possible Investors & No. of Firms & Distribution \\
\hline Indonesia & 9 & $19.1 \%$ \\
China (including Hong Kong) & 18 & $38.3 \%$ \\
Japan & 9 & $19.1 \%$ \\
Southeast Asia (excludes Indonesia) & 15 & $31.9 \%$ \\
Europe & 3 & $6.4 \%$ \\
USA & 9 & $19.1 \%$ \\
Other & 4 & $8.5 \%$ \\
\hline
\end{tabular}

Note: Total percentage is more than $100 \%$ as one firm may have multiple investors

\section{Mode of entry}

Foreign companies that enter the Indonesian market have to collaborate with an Indonesian entity. According to Anderson and Gatignon (1986)'s clustering of entry modes based on the entrant's level of control, we suggest that these comprise: dominant equity interests (majority shareholder capped at $85 \%$ per OJK regulation), balanced interests (plurality shareholders or equal partnerships), and diffused interests.

In one example of foreign capital entry as dominant majority shareholder, a Chinese P2P platform expanding to Indonesia had set up a holding company in the Cayman Islands. The company's headquarters for R\&D and product support are in China, yet its main business is set up in Indonesia through a partnership with a local company, to keep the foreign ownership at the maximum of $85 \%$ (Interview1). As one interviewee suggests, "If they (Chinese firms) want to go alone, some of them choose to go alone and just deploy to the market directly. In that case, they just find local people or a local partner and give them 15\%" (Interview8). However, as a senior VC executive noted, this approach despite common, often leads to failure due to a lack of competency in this sector (Interview25).

One of the most common ways to enter the market of P2P lending in Indonesia is through joint ventures (JV) (Interview8; Interview11; Interview19; Interview23). While in certain cases, interviewees have argued that JVs are mostly self-serving for

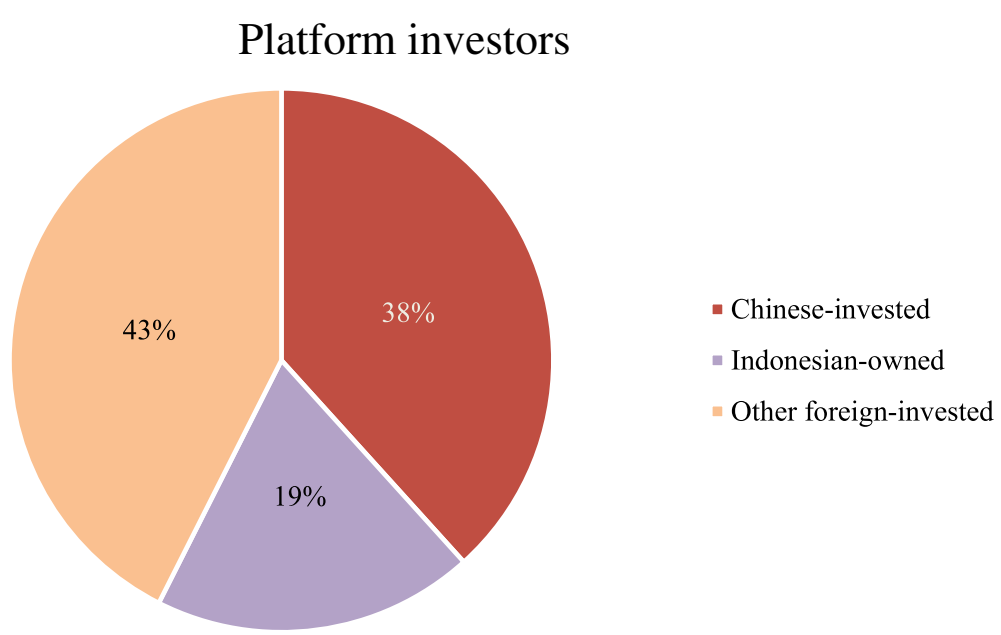

Fig. 2 Information on country of origin of platform investors of 47 registered P2P lending firms 
Chinese companies (Interview8; Interview25), there are positive examples in which there is a clear strategy to work together. Often, Chinese companies provide capital and technology, and the Indonesian partner actively provides access to and knowledge of the market, bridging their cultural gap (Interview19). For instance, WeLab, a Chinese lending fintech company, has set up a joint venture with Astra International, an Indonesian conglomerate. The JV, in which Astra International and WeLab hold $60 \%$ and $40 \%$ of ownership respectively, started with US\$21 million capital (Berita Trans 2018). On the rationale for the joint venture partnership, a Welab executive commented, "Astra is a very strong brand and a very strong local partner. They have over 50 subsidiaries, 250,000 employees and millions of customers... Welab is more of a risk and technology expert and contributes specifically to these two areas, while Astra takes care of other aspects like infrastructure services" (Interview8).

Diffused shareholder ownership often happens when a startup raises capital by issuing shares to private investors, including those from overseas, and its shareholders are diffused in their makeup. An example of foreign capital entry as a diffused shareholder is Julo, which has received Series A funding from multiple venture capital firms. One of their investors is Gobi Partners, an early stage venture capital firm from Shanghai, China (Crunchbase n.d.). Some argue that this approach is more sustainable, and includes investing groups with various degrees of proactivity in organizing resources around that investment portfolio (Interview25).

\section{Loan products}

From our data on 88 registered P2P firms, we examined the types of products offered and found that Chinese-invested platforms possess some unique traits. The most common loan types offered by Chinese-invested firms were consumer loans, followed by MSME and business loans (see Table 3). Interviews have shown that Chinese players entered the market offering short-term loans (Interview1), which typically require more advanced technology platforms and higher capital base than non-short-term loans (Interview1). Our firm-level data confirms this view. Specifically, out of 11 firms with solely Chinese links (18 if including firms with mixed shareholders that also included Chinese ones), 10 provided consumer loans (14 if including the mixed cases). Companies with solely Chinese affiliations seemed to have lower performing loan rates (PLR) but have much larger capacity for loan disbursement. Among the 29 firms offering short-term loans, 14 had some ties with Chinese investments, five had ties to other foreign investments, and the other 10 platforms' investor relationship could not be identified, proving that even among those who provide short-term loans, most came from China.

\section{Illegal platforms}

After the implementation of POJK No. 77 - OJK's first major P2P lending regulation in 2016, foreign investors in Indonesian P2P firms had to find an Indonesian partner. However, some "found the registration process cumbersome and just ran the business illegally in Indonesia" (Interview2). The former intended to create long-term businesses in Indonesia, but the latter just "had short-term goals or merely tested the waters in 
Table 3 Characteristics of lending products on registered P2P lending platforms by firm shareholders

\begin{tabular}{|c|c|c|c|c|c|c|c|c|c|}
\hline \multirow{2}{*}{$\begin{array}{l}\text { Main type of loans } \\
\text { Shareholders in firm }\end{array}$} & \multicolumn{3}{|c|}{ Consumer loans } & \multicolumn{3}{|c|}{ MSME / Business } & \multicolumn{3}{|c|}{ Other } \\
\hline & No & PLR & Loan disb. & No & PLR & Loan disb. & No & PLR & Loan disb. \\
\hline $\begin{array}{l}\text { Chinese as the only } \\
\text { foreign shareholder }\end{array}$ & 10 & $0.84-1$ & $\begin{array}{l}3652 \text { mil - } \\
15.7 \text { tril }\end{array}$ & 1 & 1 & $3242 \mathrm{mil}$ & - & - & - \\
\hline Mixed & 5 & $0.72-1$ & 0.6 tril -11 tril & 2 & 0.99 & 6.4 tril & - & - & - \\
\hline Non-Chinese & 6 & $0.97-1$ & $\begin{array}{l}6570 \text { mil - } \\
1.4 \text { tril }\end{array}$ & 16 & $0.82-1$ & $\begin{array}{l}65,080 \text { mil - } \\
16.6 \text { tril }\end{array}$ & 7 & $0.90-1$ & $\begin{array}{l}3100 \mathrm{mil}- \\
224,100 \mathrm{mil}\end{array}$ \\
\hline Information not available & 12 & $0.93-1$ & $\begin{array}{l}7141 \mathrm{mil}- \\
768,990 \mathrm{mil}\end{array}$ & 22 & $0.73-1$ & $\begin{array}{l}5047 \text { mil - } \\
1.2 \text { tril }\end{array}$ & 7 & $0.99-1$ & $\begin{array}{l}6487 \mathrm{mil}- \\
682,650 \mathrm{mil}\end{array}$ \\
\hline
\end{tabular}

Notes: No number of platforms, PLR performing loan rate for the last 90 days (TKB90 in Indonesian); Loan disb.: total value of loans disbursed in IDR. Data updated as of August 2020. Mixed cases include also cases whereby Chinese shareholders joined other local and foreign shareholders

Indonesia" (Interview2). In some cases, platforms that were initially illegal "realized that the market is good and went through the legal registration procedure with an Indonesian partner" (Interview2).

Our primary interviews and secondary sources show that Chinese capital was not only the prevalent foreign capital in legal P2P providers but also in the illegal ones (Interview1; Interview3; Interview8; Interview13). A top executive in a private equity firm explained, "When in 2016, the industry collapsed in China's P2P lending, some players migrated to Indonesia. Hence, the first generation of peer-to-peer were not the best - they were not top of the line guys. As a result, the experience that the OJK had with "Chinese platforms" was not very good. They had to deal with predatory lending, as what happened in China was replicated here. The industry there was collapsing, and here was growing and was not regulated, and those guys jumped here. The second wave of the Chinese investors were the more educated, understanding, and compliant of other countries' policy. These guys are those that want to go long-term, partner up with the right people, and do some joint research" (Interview13).

OJK periodically blocks illegal P2P firms and investigates the origin of illegal firms by tracing computer servers used by online operators. According to OJK's press release, among 227 illegal platforms blocked in July 2018, 68\% came from China. From January to February 2019, OJK blocked another 231 illegal platforms, and still, about 10\% originated from China, the largest among foreign sources (Antaranews, 2019). Our interviews also show that it is relatively simple to publish an application on Google Play or iOS App Store, and it is common for developers to publish multiple applications (Interview8). For instance, a Chinese company called "Shoujiweidai.com" had set up six different illegal platforms on Google Play, including Raja Rupiah, Rumah Pinjaman, Rupiah Bijak, Pinjaman Pintar, Danaku, Yes Rupiah (OJK 2018c). Sometimes illegal companies may also paraphrase better platforms' names, making it difficult even for top players to stay afloat (Interview19).

Such illegal operations harm many parties. The daily interest rates of up to $4 \%$ can make the sum that the users borrowed snowball by the day and eventually become too hard to repay (Interview1). According to Tongam L. Tobing, the head of OJK's Investment Alert Task Force, the money and user data can be used for 
criminal purposes such as money laundering and terrorism financing. The government also does not receive any tax revenue from illegal fintech companies, and the industry as a whole also risks losing popularity due to the public distrust of such businesses (Idnfinancial 2018).

\section{Unethical business practices}

The rapid expansion of online lending also came with rising accounts of unethical and illegal business practices, involving particularly, but not exclusively, foreign-invested firms. By the end of 2018, OJK had received over 2000 complaints about P2P lending (Maulia 2018). According to the Indonesian Consumers Foundation (YLKI), a nonprofit organization whose effort is to increase consumer's awareness of their rights and responsibilities (YLKI n.d.), online lending has received the third highest number of complaints out of all business sectors, despite it being relatively new. P2P firms with the most consumer complaints addressed to YLKI are Rupiah Plus, Pinjam Kilat, Akulaku, Dr. Rupiah, and Uang Cepat (The Jakarta Post 2019a), two of which are known as Chinese-invested firms. According to Pranata and Farandy (2019), 9\% of all negative reviews of P2P lending firms in Google Play from March 2016 to August 2018 related to unethical debt collection, with Rupiah Plus, a Chinese-invested platform, topping the number of negative reviews. Another $7 \%$ of negative Google Play reviews related to high interest rates and charges ranging from 0.2 to $3 \%$ per day $(107.4 \%$ to $4,848,172.5 \%$ annually). While interviewees often remarked that the impact of the first wave of investments was negative and harmed the reputation of Chinese investments (Interview4; Interview11; Interview13); the business practices were largely "not illegal" due to the lack of regulations and laws at the time (Interview11). These practices were not exclusive to Chinese platforms. However, the number of purely domestic platform was very limited at the time, and Chinese-invested platforms quickly became the most popular and triggered a strong market expansion. This, in turn, resulted in a spike of related malpractices.

Lending platforms obtained the borrowers' contacts and outsourced debt collection to local agents who harassed the borrowers, their families, and friends with heavyhanded measures (Iman 2018; Yuniarni 2019; Potkin et al. 2018). At times, platforms added all the debtor's contacts in a WhatsApp group to share his or her debts (Interview19). Cintia Dewi's case (Yuniarni 2019) reflects many who have been deceived by unethical platforms. She had experienced harassment by debt collectors both directly and indirectly; the debt collectors would constantly "call her and wait outside her home, and even go as far as contacting her parents, family members, friends, and acquaintances." Defaulters often borrowed from multiple platforms and were easily trapped in debt, as loans also carried a strikingly high-interest rate that made it difficult to repay interests. In Cintia Dewi's example, interest rates were 1\% per day for a maximum period of 14 days, which largely exceeds the average of $0.05-0.08 \%$ per day by legal platforms (Sugianto 2018). Similarly to the "naked loans" scandal in China in 2016, many complaints addressed to OJK involved lenders who threatened to post private information such as naked pictures acquired from users' phone galleries, or sexually harassed the borrowers online (Yuniar 2019). Often such platforms exploited the users' lack of digital literacy to access their smartphone data without their consent or 
buried the data access permission in terms and conditions to use the app so the users unknowingly gave consent to sharing the data. Borrowers had difficulty contacting the platforms that operated virtually and with an incorrect physical address to file complaints (Yuniar 2019). In addition, police investigations and prosecutions of such cases were difficult for two reasons. Firstly, most borrowers would not file official reports to the police, for the fear that they could not repay the debt. Secondly, there were still "non-existence of the laws" on online lending and data privacy, and no updated laws on consumer protection upon which the police could rely on (Interview2; Interview19; Interview23). Such unethical and illegal business practices, often employed by foreigninvested companies, also violated Indonesian religious beliefs. Hendrikus Passagi, the Director of OJK Fintech Regulation section stated, "Those practices go against God. We are a religious country. In Indonesia, if I lend the money to you and you don't pay, I will not come to your house and humiliate you" (Potkin et al. 2018).

While most of these unethical practices are verified and documented, an interviewee pointed out that there might also be organizations that use them to pursue political agendas. An interviewee felt "exponents of other industries see the P2P lending industry as threat, and they have motifs to erase this industry from Indonesia. [Name of organization] collected thousands of complaints from people, but there is a political agenda as they use these complaints to make these cases bigger and hit the OJK, rather than to resolve them and when asked, the said organization would be reluctant to share any evidence of the cases" (Interview7).

\section{Policy response and institutional change}

Main P2P lending policy

The POJK No. 77/POJK.01/2016 served as the first and fundamental regulation for online P2P lending services in Indonesia. Before, the industry was essentially in a regulatory vacuum. The regulation was "designed to protect consumers and national interests" while at the same time allow the growing of the fintech companies to support the national economy (OJK 2017a, 2017b). It stipulates clauses concerning the firm's legal entity, permissible foreign ownership up to $85 \%$, capital requirements, account requirements for borrowers and lenders, information disclosure, and referrals towards related regulations on issues such as cybersecurity and data privacy. More importantly, it mandates a "registration-trial operation-licensing" path for legal P2P players: anyone wishing to operate a legal P2P lending entity in Indonesia must first register with $\mathrm{OJK}$, then undergo a one-year operating period, and then apply to OJK for a business license (OJK 2016). By June 2020, 33 fintech P2P lending platforms had been licensed, and 128 other platforms had been registered and not yet licensed (Eloskari 2020).

In addition, the continued rise of the online P2P lending market, and the influx of Chinese and foreign investors in Indonesia have resulted in further regulatory and institutional responses, as shown in Fig. 3.

\section{Regulatory sandbox}

In mid-August 2018, OJK released the POJK No. 13/POJK.02/2018, establishing a regulatory sandbox for fintech other than P2P lending, such as credit scoring. The main 


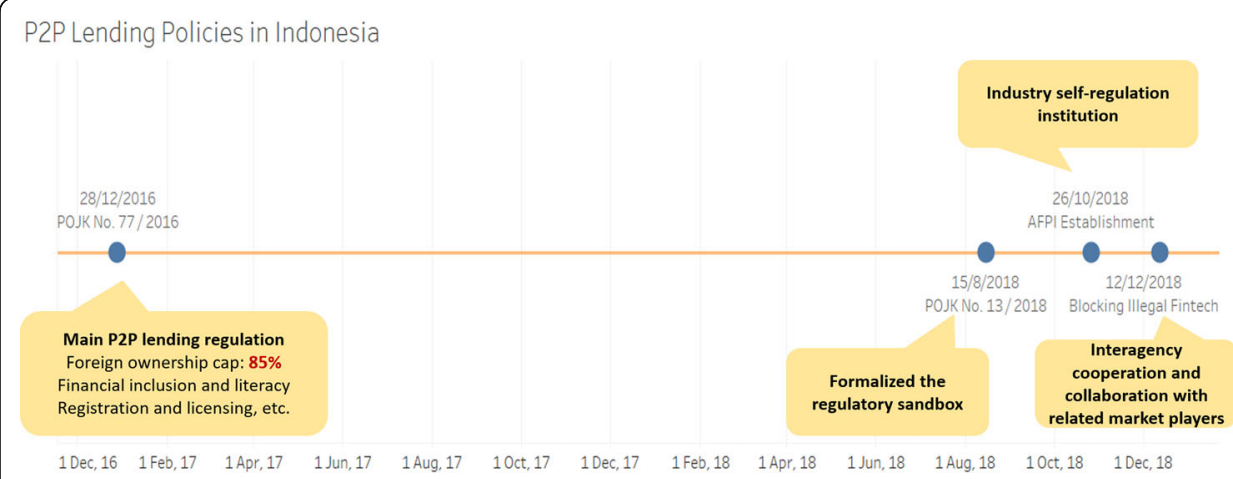

Fig. 3 Timeline of Indonesia's online P2P lending-related policies

industry advocacy group - the Indonesian Fintech Association (AFTECH) suggested this approach. In 2016, its co-founder Sebastian Togelang remarked, "What we need is a sandbox approach in which the regulator gives startups the freedom to be creative in a market but in which quality and quantity can be controlled by the regulator" (Nikkei 2016).

Similar to the regulation on P2P players, firms in the fintech sandbox need to go through three steps before applying for a business license. The first step, which is the registration, is divided into two categories, for start-ups or nonfinancial institutions and financial institutions. Financial institutions need to file registration according to the firm's sub-sectors (e.g., banking, the stock market, and non-bank financial institutions). The registration with OJK includes the application for the regulatory sandbox testing to verify whether the fintech activities abide by current regulations. OJK mandates which fintech firms need to go through the regulatory sandbox. Secondly, regulatory sandbox process, if necessary, lasts for at most one year and can be extended to up to six months. Finally, firms need to register for a license with OJK after obtaining positive sandbox testing results (OJK 2018b; Putera 2019).

\section{Professional self-regulatory institution and governance}

OJK inaugurated AFPI, a self-regulating organization (SRO) to oversee the market conduct of P2P lending firms, during the Bali Fintech Days convention on October 26, 2018 (Nabila 2018). OJK recommended AFPI's establishment "to create institutional change and development, due to the rapid expansion of the P2P lending market" (Interview2). OJK recognized the need to protect lenders against the possible fraud and personal data misuse, and borrowers against unethical loansharking activities, high-interest rates, and unreliable loan activities (Pratama 2018). As our interviews show, several members of the industry advocacy group, the Indonesian Fintech Association (AFTECH), branched out to serve in AFPI, including Adrian Gunadi (AFPI's Chairman) and Sunu Widyatmoko (AFPI's Vice Chairman). Registered P2P lending firms under OJK automatically become members of AFPI. As of August 2019, APFI spearheaded some professional self-regulation initiatives, such as the following: 
- In response to the proliferation of illegal practices in P2P lending firms in Indonesia, AFPI set up an independent ethics committee comprised of individuals without any ties to the industry, who investigate claims made by consumers against registered firms, and provide recommendations. Before, OJK was responsible to settle such complaints according to the OJK Regulation No.1/POJK.01/2013 regarding Consumer Protection in Financial Services (OJK 2015). With the new committee, AFPI and OJK effectively established a collaboration to mediate issues between registered Fintech platforms and their users(Sukmana 2018).

- AFPI released a code of market conduct for its members, including rules such as limiting the type of user data that apps can access and prohibiting online and offline harassment. In response to the complaints about high-interest rates, AFPI has also limited the interest rate of its member platforms to $0.8 \%$ per day (34\% per annual rate), with a limit of $100 \%$ of the principal for total interest and fees repayment. The collection period is limited to 90 days (AFPI 2019).

- An AFPI seminar on Indonesian regulations has become mandatory for platform directors, commissioners, and shareholders (including foreign ones such as Chinese investors) before registration with OJK (The Jakarta Post 2019b).

\section{Interagency cooperation and collaboration with related market players}

OJK has spearheaded the further effort in interagency collaboration with digital and financial market players. Through the Task Force for Handling Alleged Unlawful Acts in the Field of Collecting Community Funds and Investment Management, or the Investment Alert Task Force (SWI), OJK has joined with 12 other ministries and institutions such as the Indonesian National Police and Criminal Investigation Agency to crack down illegal fintech players (Interview23; West Java Province 2019). According to the head of SWI Tongam L Tobing, SWI has handled 2406 entities from 2018 to March 2020, and in 2019 SWI suspended the activities of 1494 illegal peer-to-peer lending platforms (Antaranews 2020). Both OJK and the Ministry of Communications and Information Technology (MOCIT) have been working with Google and Apple to ban these applications on Google Play and App Store (CNN Indonesia 2018). OJK has also regularly asked MOCIT to block the websites of illegal platforms. The Ministry of Law and Human Rights, and the National Consumer Protection Agency also partook in the Taskforce (The Jakarta Post 2019b). OJK has also required Indonesian banks to block the accounts of illegal fintech application owners and prohibit payment systems from serving illegal fintech apps. On the other hand, civil society seems to have limited operating space, because of few opportunities to engage the authorities, and limited protection for their purported beneficiaries under the current laws. As one civil society representative remarked, "It's very difficult to talk to them (OJK)...We once sent a letter. We've seen consumers coming and crying to us, but we can't deal with them one by one. Plus, we can't (as we're just facilitators). They will need to go to BPSK (the consumer protection legal institution). And, in our consumer protection laws, it lacks execution and implementation, and it is quite ambivalent too. If the perpetrator has been deemed guilty, how do we ensure that they won't do it again? In (general) court, there is an execution command, but how about in consumer 
protection court? So to tackle the problem, we must revise the consumer protection bills" (Interview23).

International collaboration among fintech regulatory agencies and business associations is also taking shape. OJK signed a memorandum of understanding (MOU) agreement with the Monetary Authority of Singapore (MAS) in October 2018 to boost fintech innovation collaboration, knowledge exchange and regulatory environment training for firms in each other's market (MAS 2018). In addition to formal intergovernmental cooperation, the self-regulatory industry association has conducted crosscountry knowledge exchanges with other foreign associations. For instance, AFPI has worked with the Beijing Internet Finance Association to share knowledge about the market and investment challenges, and has involved OJK in sharing the regulatory practices (Interview13).

\section{Regulatory and institutional response between Indonesia and China: a comparison}

Broadly speaking, Indonesia's regulatory and institutional responses to tame risks from fintech expansion bear both similarities and differences with the actions undertaken by Chinese regulators. Both governments have imposed industry-specific regulations to regulate firm performance in a wide range of areas, although the specific regulatory requirements differ. Both governments have also worked with major industry players to launch self-regulatory associations responsible for overseeing the market conduct. Both governments have waged campaigns against illegal fintech players through interagency collaboration with market players. There have also been rising interests and efforts for international coordination with other countries in regulation, though coordination between the two countries is still nascent.

Yet the two countries also show notable differences in current approaches. Indonesia's regulatory sandbox for fintech other than P2P lending, which China does not have, shows that Indonesia follows the lead of countries like UK and Australia in taking an encouraging stance towards new business innovations, preferring to work with emerging technologies and startups by keeping them under the regulators' watch during the testing period. Specific regulatory differences, like Indonesia's regulation that foreign investors can own up to $85 \%$ of the total shares of a P2P lending firm, also show that Indonesia is still keen for the sector to expand with foreign investments, while also hoping that domestic players will be able to benefit and learn from foreign partners or investors. Other Indonesia-specific regulatory requirements, such as the mandate that firms must support activities that promote financial inclusion and literacy, show that fintech lending is still viewed as vital to boosting financial inclusion in Indonesia. While Chinese regulators have significantly clamped down on risky P2P platforms and mandated the transition of existing platforms to online small lending firms, Indonesia is still betting on P2P lending to help meet the credit demand of the underbanked.

\section{Conclusion}

Regulating emerging technologies without stifling business innovation and economic growth can be challenging for policymakers. This paper has shown how, in the cases of Indonesia's online P2P lending, regulators tended towards a reactive approach, which however established a novel system of regulations and institutional collaboration to 
tackle the adverse negative effects of these activities. In the face of foreign capital flows powering the growth of fintech, specifically the influx of Chinese capital driven to under-regulated growth markets by stringent regulations at home, the Indonesian state has swiftly responded to facilitate the sector's expansion and tame related risks. The state has done so by not only imposing new rules and regulatory mechanisms but also branching out to other government agencies and creating government-linked organizations to delegate the task of professional regulation and industry practices monitoring.

While the current regulatory approach in Indonesia proved timely, we recommend several ways through which its policymakers could strengthen the governance of online lending:

Firstly, P2P lending would benefit from the implementation of much-needed laws and broader regulatory frameworks that address existing and emerging risks from market expansion. For instance, with the high incidence of data privacy breaches, it is imperative that national governments implement a general data privacy bill, like the EU General Data Protection Regulation (GDPR). Current privacy and cybersecurity regulations in Indonesia, as stated in Law (Undang-Undang or UU) No. 8/2011 regarding Electronic Information and Transactions, as well as the Ministry of Communications and Information Technology (MOCIT) Regulation No. 20/2016 on Personal Data Protection in Electronic Systems, are unsuitable for preventing large-scale breaches and do not allow for damage recovery. The Indonesian draft law on personal data protection was signed by President Joko Widodo and passed to the House of Representatives for discussion in January 2020 (Carl and Wirabuana 2020).

Secondly, closer collaborations within government agencies and between the government, civil society groups, and industry associations would be vital for the sake of integrating and analyzing data from different sources and strengthening the firms' regulatory compliance. Examples of civil society and self-regulating associations participating in the governance of emerging technologies like fintech can be found in other countries. For instance, China's self-regulatory industry associations have worked closely with government regulators to strengthen the regulatory control over risks in P2P lending, as noted earlier in this paper. To counter cyber risks such as identity theft, citizens and community-level organizations in countries such as New Zealand, Singapore, and Australia are encouraged to participate in cybersecurity information sharing and have hotlines to report adverse cyber events (Thinyane and Christine 2020). Citizens and civil society organizations in Indonesia, as the paper noted earlier, have limited channels to communicate with regulators directly, and professional selfregulatory institutions like AFPI have served as intermediaries. More synergies between the regulators and the civil society representing relevant interest groups such as consumers, in addition to the professional self-regulatory institution like the AFPI ethics committee, would be beneficial. Such a whole-of-society, more proactive and timely approach can help to regulate fintech risks and protect the interests of the public before widespread adverse impacts occur.

Thirdly, policymakers and business associations could consider strengthening international cooperation in regulation and law enforcement, knowledge and technology exchange with the regulators, business associations, and fintech market players in main investor countries like China and other Southeast Asian countries, and within international multilateral networks. Common international coordination arrangements 
range from bilateral agreements and initiatives (e.g., fintech MOU), to multilateral ones coordinated by international institutions (such as FSB's Financial Innovation Network). Current collaboration and communication efforts involving Indonesian regulators and associations, as noted in this paper, between OJK and MAS, and between AFPI and Beijing Internet Finance Association, are good starting points. In addition, Indonesia may consider joining new multilateral networks, such as the Global Financial Innovation Network launched in 2019 to exchange learnings, develop a common sandbox and help firms navigate between different jurisdictions as they aim for scale internationally (Taylor et al. 2020).

This study provided an initial framework for analyzing the online P2P lending market expansion driven by foreign capital and the policy responses and institutional changes to mitigate risks. Future empirical research should strengthen the understanding of transboundary capital flows and analyze the business practices of foreign-invested fintech firms and their impact on domestic market players. Future research should examine additional cases of regulatory and institutional responses to the expansion of online lending markets in developing countries, to allow for cross-country comparisons and identify innovative policy solutions. This would also help to develop stronger theoretical frameworks that broadly examine the growth of emerging technology sectors in emerging markets powered by transnational capital. It would also inform both scholars and policymakers of the best practices in governance to balance innovation and growth with policy intervention and risk mitigation.

Acknowledgements

We acknowledge the generous help of Professor Albert Park and Professor Maoliang Bu in providing useful comments and suggestions.

\section{Authors' contributions}

Angela Tritto conducted the qualitative data collection and analysis, wrote the introduction, the methodology, results of the manuscript, helped organize the second round of interviews, and coordinated the writing on the different sections. Yujia He conducted the literature review, the in-person interviews, qualitative data collection and analysis, translation of Chinese-language interviews, co-wrote the results of the manuscript, and wrote the conclusion. Victoria Amanda Junaedi was responsible for quantitative data collection and analysis on Indonesian P2P firms, translation of Bahasa-language interviews, and qualitative data collection. All authors read and approved the final manuscript.

\section{Authors' information}

Angela Tritto is an Adjunct Assistant Professor at the Division of Public Policy and a Postdoctoral Fellow jointly appointed by the Institute of Emerging Market Studies and by the Division of Social Science at the Hong Kong University of Science and Technology. She is currently working on three interrelated research projects on the Belt and Road Initiative in Southeast Asia. Her research interests include management of innovation, environmental policies and technologies, heritage management, and sustainable development. She recently published several works in collaboration with a team of international scholars on the sustainability of the Belt and Road Initiative. Her past publications examine environmental innovations and the role of institutions in the management of World Heritage Sites in China and Malaysia. She holds a PhD from City University of Hong Kong.

Dr. Yujia He is an assistant professor at the Patterson School of Diplomacy and International Commerce, University of Kentucky, USA. Her areas of expertise are international political economy and science and technology policy. Previously she was a Postdoctoral Fellow at the HKUST Institute for Emerging Market Studies (IEMS). She also worked in Washington D.C. as a visiting fellow for the Atlantic Council and as a researcher for the Wilson Center. She has published journal articles on the trade and governance of critical minerals, and policy reports on Chinese overseas investment, smart city development, artificial intelligence policy, data privacy governance, and citizen science. She obtained her PhD in International Affairs, Science and Technology (IAST) and MS in International Affairs from Georgia Tech, BS in Chemistry from Peking University and Stanford China Program certificate. Victoria Amanda Junaedi is currently working as a Consultant in IBM. She recently graduated from the Hong Kong University of Science and Technology (HKUST), China, with a Bachelor of Science in Economics and Finance. Her research interests are financial technology, economic and public policy analysis. Previously, she worked as a research assistant at the HKUST Institute for Emerging Market Studies (IEMS), for research projects on the Belt and Road Initiative in Southeast Asia and fintech investments in Indonesia. Her undergraduate thesis explores the factors that affect a successful loan on an online microlending platform using econometric analysis. She also has working experience in management consulting, e-commerce, and financial technology. 


\section{Funding}

This research project was partially funded by the Strategic Public Policy Research Funding Scheme from the Central Policy Unit of the Hong Kong Special Administrative Region Government, China (Project Number: S2016.A7.003).

\section{Availability of data and materials}

The qualitative datasets generated during and analysed during the current study are not publicly available due to the confidentiality and anonymity of interviews but are available from the corresponding author on reasonable request. The quantitative datasets generated during and analysed during the current study are available from the corresponding author on reasonable request.

\section{Competing interests}

The authors declare that they have no competing interests.

\section{Author details}

${ }^{1}$ Institute for Emerging Market Studies, The Hong Kong University of Science and Technology, Lo Ka Chung Building, Clear Water Bay, Kowloon, Hong Kong SAR, China. ${ }^{2}$ Patterson School of Diplomacy and International Commerce, University of Kentucky, Lexington, KY 40506, USA. ${ }^{3}$ Business School, The Hong Kong University of Science and Technology, Clear Water Bay, Kowloon, Hong Kong SAR, China.

Received: 5 March 2020 Accepted: 6 September 2020

Published online: 26 November 2020

\section{References}

AFP, 2016. Naked selfies used as collateral for Chinese loans. https://www.yahoo.com/news/naked-selfies-used-collateralchinese-loans-111137036.html. Accessed 11 June 2019.

AFPI, 2019. Guidelines (in Indonesian). https://www.afpi.or.id/detailsnews/17. Accessed 11 June 2019.

Amankwah-Amoah J (2019) Technological revolution, sustainability, and development in Africa: overview, emerging issues, and challenges. Sustain Dev 27(5):910-922

Anderson E, Gatignon H (1986) Modes of foreign entry: a transaction cost analysis and propositions. J Int Bus Stud 17(3):1-26

Antaranews, 2019. Illegal foreign fintech firms come from China, Russia, S Korea https://en.antaranews.com/news/122265/ illegal-foreign-fintech-firms-come-from-china-russia-s-korea. Accessed 11 June 2019

Antaranews, 2020. SWI reveals 388 illegal lending fintech entities. https://en.antaranews.com/news/143662/swi-reveals-388illegal-lending-fintech-entities. Accessed 1 Aug 2020

Bateman M, Duvendack M, Loubere N (2019) Is fin-tech the new panacea for poverty alleviation and local development? Contesting Suri and Jack's M-Pesa findings published in science. Rev Afr Polit Econ 46(161):480-495

Berita Trans, 2018. Dengan Modal Awal US\$21 Juta, Astra dan Welab Bangun AWDA di Indonesia [With US \$ 21 Million Capital, Astra and Welab Build AWDA in Indonesia]. http://beritatrans.com/2018/09/05/dengan-modal-awal-us21-jutaastra-dan-welab-bangun-awda-di-indonesia/. Accessed 11 June 2019

Braithwaite J (2008) Regulatory capitalism: how it works, ideas for making it work better. Edward Elgar, Cheltenham

Buckley RP, Webster S (2016) FinTech in developing countries: charting new customer journeys. J Financ Transformation 44: 151-159

Cambridge Center for Alternative Finance, 2018. The 3rd Asia Pacific region alternative finance industry report. https:/www. jbs.cam.ac.uk/fileadmin/user_upload/research/centres/alternative-finance/downloads/2018-3rd-asia-pacific-alternativefinance-industry-report.pdf. Accessed 11 June 2019

Carl, M. S., and Wirabuana, R.N., 2020. Indonesia's new data protection rules move toward passage. https://www.lexology. com/library/detail.aspx?g=6641 bd74-b4fd-498c-a0b9-d98fbb093b6d. Accessed 30 July 2020.

Carroll T, Jarvis DS (eds) (2017) Asia after the developmental state: Disembedding autonomy. Cambridge University Press, Cambridge (UK)

CBRC (China Banking Regulatory Commission), 2016a. 关于印发《P2P网络借贷专整治工作实施方案》的通知 [Notice on Issuing the Implementation Plan for the Special Campaign on Online P2P Lending Risks]. http://www.cbrc.gov.cn/ chinese/home/docDOC ReadView/D81B52D3D20A49A99522C48FA8F1C752.html. Accessed 11 June 2019

CBRC (China Banking Regulatory Commission), 2016b. 网络借贷信息中介机构备案登记管理指引[Guidance of Online Lending Information Intermediary Institutions Recordation Administration]. http://www.cbrc.gov.cn/govView_E7B94B41 E8C340E4833472632308AEC5.html. Accessed 11 June 2019

CBRC (China Banking Regulatory Commission), 2017a. 中国银监会办公厅关于印发网络借贷资金存管业务指引的通知 [Notice on Issuing the Guidelines for the Online Lending Fund Depository Business]. http://www.cbrc.gov.cn/govView_42 01EF03472544038242EED1878597CB.html. Accessed 11 June 2019

CBRC (China Banking Regulatory Commission), 2017b. 中国银监会办公厅关于印发网络借贷信息中介机构业务活动 信息 披露指引的通知 [Notice on Issuing the Guidelines for the Disclosure of Information on the Business Activities of Online Lending Information Intermediary Institutions]. http://www.cbrc.gov.cn/govView_C8D68D4C980A4410B9F4E21BA593B4F2. html. Accessed 11 June 2019

CBRC (China Banking Regulatory Commission), the Ministry of Industry and Information Technology, the Ministry of Public Security and the State Internet Information Office, 2016. 网络借贷信息中介机构业务活动管理暂行办法 [nterim Measures for the Administration of the Business Activities of Online Lending Information Intermediary Institutions]. http://www.miit.gov.cn/n1146295/n1146557/n1146624/c5218617/content.html. Accessed 11 June 2019

China Internet Network Information Center (CNNIC), 2020. 中国互联网络发展状况统计报告 [Statistical Report on Internet Development in China]. http://www.cac.gov.cn/gzzt/ztzl/zt/bg/A0920010206index_1.htm. Accessed 29 July 2020

Claessens S, Frost J, Turner G, Zhu F (2018) Fintech credit markets around the world: size, drivers and policy issues. In: BIS Quarterly Review. https://www.bis.org/publ/qtrpdf/r_qt1809e.htm. Accessed 11 June 2019

Clarke C (2019) Platform lending and the politics of financial infrastructures. Rev Int Polit Econ 26(5):863-885 
CNN Indonesia, 2018. Gandeng Google dan Apple, Kominfo Lenyapkan Fintech llegal [In Collaboration with Google and Apple, Kominfo Removes Illegal Fintech]. December 17. https://www.cnnindonesia.com/teknologi/20181217175051-1 85-354348/gandeng-google-dan-apple-kominfo-lenyapkan-Fintech-ilegal. Accessed 11 June 2019

CrunchBase. n.d.. Julo. https://www.crunchbase.com/organization/julo-2. Accessed 11 June 2019

Davis K, Maddock R, Foo M (2017) Catching up with Indonesia's Fintech industry. Law Financ Mark Rev 11(1):33-40

Ehrentraud J, Ocampo DG, Garzoni L, Piccolo M (2020) Policy responses to fintech: a cross-country overview. In: FSI Insights on policy implementation. Bank for International Settlements https://www.bis.org/fsi/publ/insights23.pdf. Accessed 1 Aug 2020

Eloskari, E. A., 2020. P2P lending platforms struggle with risky loans amid COVID-19. The Jakarta Post. June 4. https://www. thejakartapost.com/news/2020/06/03/p2p-lending-platforms-struggle-with-risky-loans-amid-covid-19.html. Accessed 1 Aug 2020

EY, 2017. EY Fintech adoption index 2017. https://www.ey.com/Publication/vwLUAssets/ey-fintech-adoption-index-2017/ \$FILE/ey-fintech-adoption-index-2017.pdf. Accessed 11 June 2019

Feng, E., 2018. Chinese government faces peer-to-peer lending scandals dilemma. Financial Times https://www.ft.com/ content/c71eea4a-c198-11e8-84cd-9e601db069b8. Accessed 11 June 2019

FSB (Financial Stability Board) (2017) FinTech credit: market structure, Business models and financial stability implications. In: Committee on the Global Financial System (CGFS) Report https://www.fsb.org/wp-content/uploads/CGFS-FSB-Report-onFinTech-Credit.pdf. Accessed 7 Aug 2020

Gruin J, Knaack P (2019) Not just another shadow bank: Chinese authoritarian capitalism and the 'developmental' promise of digital financial innovation. New political Economy 25(3):1-18

Hootsuite, 2018. Digital in 2018 in Southeast Asia. Essential insights into internet, social media, mobile, and e-commerce use across the region https://aseanup.com/southeast-asia-digital-social-mobile/. Accessed 11 June 2019

Huang RH (2018) Online P2P lending and regulatory responses in China: opportunities and challenges. Eur Bus Organ Law Rev 19(1):63-92

Idnfinancial, 2018. OJK: a lot of illegal fintech companies come from China. https://www.idnfinancials.com/archive/news/1 7444/OJK-A-lot-of-illegal-fintech-companies-come-from-China. Accessed 11 June 2019

Iman N (2018) Assessing the dynamics of Fintech in Indonesia. Investment Manag Financ Innov 15(4):296-303

Internetworldstats, 2018. Internet Usage in Asia. https:/www.internetworldstats.com/stats3.htm. Accessed 11 June 2019

Iwasaki K (2018) Emergence of Fintech Companies in Southeast Asia_Rising Hopes of a Solution to Financial Issues. Pac Bus Ind XVIII(68) https:/www.jri.co.jp/MediaLibrary/file/english/periodical/rim/2018/68.pdf. Accessed 11 June 2019

Jao, N., 2019. Chinese P2P lending platforms look to Southeast Asia amid industry purge back home. Technode, 20 June. https://technode.com/2019/06/20/china-p2p-southeast-asia/. Accessed 7 Aug 2020

Jarvis DSL (2012) The regulatory state in developing countries: can it exist and do we want it? The case of the Indonesian power sector. J Contemp Asia 42(3):464-492

Jayasuriya K (2001) Globalization and the changing architecture of the state: the regulatory state and the politics of negative co-ordination. J Eur Public Policy 8(1):101-123

Jenik I, Lauer K (2017) Regulatory sandboxes and financial inclusion. Working Paper. CGAP, Washington, D.C. https://www. cgap.org/sites/default/files/researches/documents/Working-Paper-Regulatory-Sandboxes-Oct-2017.pdf

Jiang, X., 2018. More steps mulled to curb monetary risks, China Daily, 15 June. https://www.chinadailyhk.com/ articles/114/125/31/1529025150625.html

Johnson C (1982) MITI and the Japanese miracle: the growth of industrial policy: 1925-1975. Stanford University Press, Stanford, CA

Kagan, J., 2018. Payday Loan. Investopedia. https://www.investopedia.com/terms/p/payday-loans.asp Accessed 11 June 2019

Lai KP, Samers M (2020) Towards an economic geography of FinTech. Prog Hum Geogr https://doi.org/10.1177\%2F03 09132520938461

Leavenworth S (2016) China's 'naked loans' force female students to bare all in return for more cash. The Guardian. https:// www.theguardian.com/world/2016/jun/15/chinas-naked-loans-force-female-students-to-bare-all-in-return-for-more-cash. Accessed 11 June 2019

Lee A (2020) China's scandal-plagued P2P sector faces 'continued pressure' in 2020 amid tightening regulation. South China Morning Post https://www.scmp.com/economy/article/3045006/chinas-scandal-plagued-p2p-sector-faces-continuedpressure-2020-amid. Accessed 1 Aug 2020

Li, C, Stevenson, A. and Wee, S.L., 2018. As Chinese investors panic over dubious products, Authorities Quash Protests New York Times https://www.nytimes.com/2018/08/09/business/chinese-lending-platform-panic-protests.html. Accessed 11 June 2019

Liu, J., 2018a. The rise and fall of China's online P2P lending. TechNode https://technode.com/2018/08/02/the-rise-and-fall-ofchinas-online-p2p-lending/. Accessed 11 June 2019

Liu Q (2018b) 合规大限临近 “三证齐全”网贷平台仅有110余家 [deadline nears for regulatory approval inspection, yet only one-tenth of P2P platforms have obtained all three licenses]. Securities Daily http://finance.china.com.cn/money/ efinance/20181214/4838860.shtml. Accessed 11 June 2019

Loubere N (2017) China's internet finance boom and tyrannies of inclusion. China Perspect 4:9-18

Malady L, Buckley RP, Didenko A, Tsang CY (2018) A regulatory diagnostic toolkit for digital financial services in emerging markets. Bank Financ Law Rev 34(1):1-30

Maulia E (2018) Indonesia tightens screws on peer-to-peer lenders. Nikkei Asian Rev https://asia.nikkei.com/Spotlight/SharingEconomy/Indonesia-tightens-screws-on-peer-to-peer-lenders. Accessed 11 June 2019

Monetary Authority of Singapore (MAS), 2018. Indonesia and Singapore strengthen cooperation in FinTech. http://www.mas. gov.sg/News-and-Publications/Media-Releases/2018/Indonesia-and-Singapore-strengthen-cooperation-in-FinTech.aspx. Accessed 11 June 2019

Morgan Stanley Research, 2015. Global marketplace lending: disruptive innovation in financials. https://bebeez.t/wp-content/ blogs.dir/5825/files/2015/06/GlobalMarketplaceLending.pdf. Accessed 11 June 2019

Nabila M (2018) OJK Resmikan Kehadiran AFPI, Asosiasi Khusus Fintech Lending [OJK Inaugurates AFPI, Fintech Lending Special Association]. Dailysocial.id https://dailysocial.id/post/asosiasi-Fintech-lending. Accessed 11 June 2019 
Nikkei, 2016. Indonesian P2P industry seeks regulatory clarity. https:/asia.nikkei.com/Business//rends/Indonesian-P2P-industryseeks-regulatory-clarity. Accessed 11 June 2019

OJK, 2015. Consumer Protection in Financial Services (POJK No. /POJK.07/2013). https://www.ojk.go.id/id/kanal/edukasi-danperlindungan-konsumen/regulasi/peraturan-ojk/Pages/POJK-Perlindungan-Konsumen.aspx\#. Accessed 11 June 2019

OJK, 2016. POJK Nomor 77/POJK.01/2016 tentang Layanan Pinjam Meminjam Uang Berbasis Teknologi Informasi [Lending Services with Information Technology (POJK No. 77/POJK.01/2016)]. https://www.ojk.go.id/id/regulasi/otoritas-jasakeuangan/peraturan-ojk/Pages/POJK-Nomor-77-POJK.01-2016.aspx. Accessed 11 June 2019

OJK, 2017a. Press Release: OJK Issues Regulation on IT-Based Lending Services. https://www.ojk.go.id/en/berita-dan-kegiatan/ siaran-pers/Pages/Press-Release-OJK-Issues-Regulation-on-It-Based-Lending-Services.aspx. Accessed 11 June 2019

OJK, 2017b. OJK circular letter No. 18/SEOJK.02/2017 (in Indonesian). https:/www.ojk.go.id/id/regulasi/otoritas-jasa-keuangan/surat-edaranojk-dan-dewan-Komisioner/Documents/Pages/SEOJK-Tata-Kelola-dan-Manajemen-Risiko-Teknologi-Informasi-pada-Layanan-PinjamMeminjam-Uang-Berbasis-Teknologi-Informasi/SAL\%20SEOJK\%2018\%20FINTECH.pdf. Accessed 11 June 2019

OJK, 2018a. Ikhtisar data Keuangan Fintech (peer to peer lending) Periode Oktober 2018 [financial data overview of Fintech (peer to peer lending) period October 2018]. https://www.ojk.go.id/id/kanal/iknb/data-dan-statistik/Fintech/Pages/khtisarData-Keuangan-Fintech-(Peer-To-Peer-Lending)-Periode-Oktober-2018.aspx. Accessed 11 June 2019

OJK, 2018b. Inovasi keuangan digital di sektor jasa keuangan [Digital Financing Innovation in Financial Services (POJK No. 13/ POJK.02/2018)]. https://www.ojk.go.id/id/regulasi/Documents/Pages/Inovasi-Keuangan-Digital-di-Sektor-Jasa-Keuangan/ pojk13-2018.pdf. Accessed 11 June 2019

OJK, 2018c. Daftar Platform Fintech Lending yang Belum Terdaftar atau Berizin [List of Unregistered or Unlicensed Fintech Lending Platforms]. https://www.ojk.go.id/id/berita-dan-kegiatan/siaran-pers/Documents/Pages/Siaran-Pers-SatgasKembali-Temukan-182-Fintech-Peer-To-Peer-Lending-Tanpa-Izin/DAFTAR\%20Fintech\%20LENDING\%20TAK\%20BERIZIN\%2 0-\%20SEPT\%20(1).pdf. Accessed 11 June 2019

OJK, 2019. Penyelenggara Fintech Terdaftar di OJK per Desember 2018 [Fintech Firms Registered at OJK as of December 2018]. https://www.ojk.go.id/id/berita-dan-kegiatan/publikasi/Pages/Penyelenggara-Fintech-Terdaftar-di-OJK-perDesember-2018.aspx. Accessed 11 June 2019

Palmié M, Wincent J, Parida V, Caglar U (2020) The evolution of the financial technology ecosystem: an introduction and agenda for future research on disruptive innovations in ecosystems. Technol Forecast Soc Chang 151:119779

Pei S (2018) Singapore approach to develop and regulate FinTech. In: Handbook of blockchain, digital finance, and inclusion: Cryptocurrency, FinTech, InsurTech, and regulation. 1, 347-357. Research Collection Lee Kong Chian School of Business https://ink.library.smu.edu.sg//kcsb_research/5911. Accessed 11 June 2019

People's Bank of China (PBOC), 2015. 人民银行等十部门发布《关于促进互联网金融健康发展的指导意见》[Guiding Opinions on Promoting the Sound Development of Internet Finance]. http://www.gov.cn/xinwen/2015-07/18/content_2 899360.htm. Accessed 11 June 2019

People's Daily, 2019. 北京互金协会将陆续公布P2P平台借款人逃废债名单 [Beijing internet finance association will release list of P2P lending platform borrowers with unpaid and runaway debts]. http://money.people.com.cn/n1/2019/0203/c42 877-30611858.html. Accessed 30 July 2020.

Potkin F, Zhang S, Diela T (2018) RPT-A call to the boss: Indonesia contends with aggressive Chinese online lenders. Reuters https://www.reuters.com/article/china-p2p-indonesia-idUSL4N1WA1HO. Accessed 11 June 2019

Pranata N, Farandy AR (2019) Big data-based peer-to-peer lending FinTech: surveillance system through the utilization of a Google play review. ADBI working paper 943. Asian Development Bank Institute, Tokyo

Pratama AH (2018) Fokus P2P Lending, Asosiasi Fintech Pendanaan Bersama Indonesia Resmi Berdiri The Indonesian Fintech Joint Funding Association that focuses on P2P lending is officially established]. Tech in Asia. https://id.techinasia.com/ asosiasi-Fintech-pendanaan-bersama-indonesia. Accessed 11 June 2019

PRC (People's Republic of China) Ministry of Education, and China Banking and Insurance Regulatory Commission (CBRC), 2016. 教育部办公厅中国银监会办公厅关于加强校园不良网络借贷风险防范和教育引导工作的通知 [Notice on increasing risk prevention and education guidance measures for bad student loans]. http://www.moe.gov.cn/srcsite/A12/ s7060/201605/t20160504_241921.html. Accessed 11 June 2019

Pulse Lab Jakarta, 2018. Banking on Fintech: financial inclusion for micro Enterprises in Indonesia. https://pulselabjakarta.org/ assets/uploadworks/2018-09-03-19-25-05.pdf. Accessed 6 Oct 2019

Putera, A. D., 2019. Ini Tahapan Pendaftaran Fintech dan Cara OJK Melakukan Pengawasan This is the Stage of Fintech Registration and the Way the OJK Conducts Supervision] Kompas.com. https://ekonomi.kompas.com/read/2018/09/01/2 05343526/ini-tahapan-pendaftaran-Fintech-dan-cara-ojk-melakukan-pengawasan. Accessed 11 June 2019

PwC, 2019. Indonesia's Fintech lending: driving economic growth through financial inclusion. www.pwc.com/id/fintechlending. Accessed 6 Oct 2019.

Research and Markets, 2017. Global peer to peer lending market by end-user (consumer credit loans, Small Business Loans, Student Loans, and Real Estate Loans) and Business Model Type (Alternate Marketplace Lending and Traditional Lending) https://www.researchandmarkets.com/research/s4bsn8/global_peer_to. Accessed 11 June 2019

Reuters, 2019. China gives P2P lenders two years to exit industry: document. https://www.reuters.com/article/us-china-p2pidUSKBN1Y2039. Accessed 1 Aug 2020

Rock M, Murphy JT, Rasiah R, van Seters P, Managi S (2009) A hard slog, not a leap frog: globalization and sustainability transitions in developing Asia. Technol Forecast Soc Chang 76(2):241-254

Santoso W, Trinugroho I, Risfandy T (2019) What determine loan rate and default status in financial technology online direct lending? Evidence from Indonesia. Emerg Mark Financ Trade 56(2):351-369

Shaydullina VK (2018) Review of institutional and legal issues for the development of the FinTech industry. Eur Res Stud 21: $171-178$

Shen W (2015) Internet lending in China: status quo, potential risks and regulatory options. Comput Law Secur Rev 31(6): 793-809

Shim Y, Shin D-H (2016) Analyzing China's Fintech industry from the perspective of actor-network theory. Telecommun Policy 40(2-3):168-181

Singh JP (2019) Development finance 2.0: do participation and information technologies matter? Rev Int Polit Econ 26(5): $886-910$ 
Stern C, Makinen M, Qian Z (2017) FinTechs in China-with a special focus on peer to peer lending. J Chin Econ Foreign Trade Stud 10(3):215-228

Stevenson A, Li C (2017) China's new lenders collect invasive data and offer billions. Beijing is worried. New York Times https://www.nytimes.com/2017/12/25/business/china-online-lending-debt.html. Accessed 11 June 2019

Sugianto D (2018) Biar Tak Jadi Korban, Kenali Dulu Penyedia Utang Online-nya [Let It Not Be a Victim, First Recognize Its Online Debt Provider]. Detikfinance. https://finance.detik.com/moneter/d-4343892/biar-tak-jadi-korban-kenali-dulupenyedia-utang-online-nya. Accessed 11 June 2019

Sukmana, Y. (2018). Asosiasi Fintech Janji Bantu Cari Solusi Korban Pinjaman Online, Asal.... https://ekonomi.kompas.com/ read/2018/12/14/201900726/asosiasi-Fintech-janji-bantu-cari-solusi-korban-pinjaman-online-asal-.

Supreme People's Court of China, 2015. 最高人民法院关于审理民间借贷案件适用法律若干问题的规定 [Provisions of the Supreme People's Court on Several Issues concerning the Application of Law in the Trial of Private Lending Cases]. https://www.chinacourt.org/law/detail/2015/08/id/148349.shtml. Accessed 11 June 2019

Suryono RR, Purwandari B, Budi I (2019) Peer to peer (P2P) lending problems and potential solutions: a systematic literature review. Procedia Comput Sci 161:204-214

Taylor RC, Wilson C, Holttinen E, Anastasiia M (2020) Institutional arrangements for Fintech regulation and supervision, IMF Fintech Note, International Monetary Fund, Washington, DC https:/www.elibrary.imf.org/view/IMF063/28504-9781513520308/285049781513520308/28504-9781513520308 A001.xml?rskey=9NH3FD\&result=78\&redirect=true. Accessed 31 July 2020

Thakor AV (2020) Fintech and banking: what do we know? J Financ Intermed 41:100833

The Jakarta Post, 2019a. P2P lending third most complained about business sector. https://www.thejakartapost.com/news/2 019/01/30/p2p-lending-third-most-complained-about-business-sector.html. Accessed 11 June 2019

The Jakarta Post, 2019b. 145 more P2P lenders seek licenses from OJK. https://www.thejakartapost.com/news/2019/03/ 08/145-more-p2p-lenders-seek-licenses-from-ojk.html. Accessed 11 June 2019

Thinyane M, Christine D (2020) Co-production of cyber resilience in Asia and the Pacific: abridged preliminary report. United Nations University Institute in Macau https://i.unu.edu/media/cs.unu.edu/page/4531/Preliminary-Report.pdf. Accessed 31 July 2020

Tsai K (2017) Fintech and financial inclusion in China. HKUST IEMS Thought Leadership Brief https://iems.ust.hk/tlb20. Accessed 11 June 2019

Wade R (1990) Governing the market: economic theory and the role of government in east Asian industrialization. Princeton University Press, Princeton

Wang H, Kou G, Peng Y (2020) Multi-class misclassification cost matrix for credit ratings in peer-to-peer lending. J Oper Res Soc:1-12

Wang J (2018a) From aperture satellite to "internet finance": institutionalization of ICTs in China's financial sector since 1991. Telecommun Policy 42(7):566-574

Wang J (2018b) Inclusion or expulsion: Digital technologies and the new power relations in China's "Internet finance". Commun Public 3(1):34-45

Weiss L (1998) The myth of the powerless state. Governing the economy in a global era. Polity Press, Oxford

West Java Province, 2019. OJK Urges To be aware of Illegal Financial Technology (Fintech). https://www.jabarprov.go.id/En/ index.php/news/8264/2019/08/09/OJK-Urges-To-Be-aware-of-lllegal-Financial-Technology-Fintech. Accessed 15 Oct 2019

World Bank, 2017a. The global Findex database. https://globalfindex.worldbank.org/. Accessed 11 June 2019

World Bank, 2017b. MSME Financing Gap. https://www.smefinanceforum.org/sites/default/files/Data\%20Sites\%20downloads/ MSME-Finance-Gap-2017-public.xlsx. Accessed 11 June 2019

Xu D, Tang S, Guttman D (2019) China's campaign-style internet finance governance: causes, effects, and lessons learned for new information-based approaches to governance. Comput Law Secur Rev 35(1):3-14

Yang D, Chen P, Shi F, Wen C (2018) Internet finance: its uncertain legal foundations and the role of big data in its development. Emerg Mark Financ Trade 54:721-732

Yin RK (2003) Case study research. Design and methods. SAGE Publications, Thousand Oaks

YLKI, n.d.. Yayasan Lembaga Konsumen Indonesia [Indonesian Consumers Foundation]. http://ylki.or.id/profil/tentang-kami/. Accessed 11 June 2019

You C (2017) Recent development of FinTech regulation in China: a focus on the new regulatory regime for the P2P lending (loan-based Crowdfunding) market. Cap Mark Law J 13(1):85-115

Yu T, Shen W (2019) Funds sharing regulation in the context of the sharing economy: understanding the logic of China's P2P lending regulation. Comput Law Secur Rev 35(1):42-58

Yuniar RW (2019) Indonesia's online P2P loan sharks are driving people to suicide. South China Morning Post https://www. scmp.com/print/week-asia/economics/article/2188185/indonesias-online-p2p-loan-sharks-are-driving-people-suicide Accessed 11 June 2019

Yuniarni S (2019) Consumers face harassment by Fintech debt collectors due to weak data protection. Jakarta Globe https:/ jakartaglobe.id/context/consumers-face-harassment-by-Fintech-debt-collectors-due-to-weak-data-protection. Accessed 11 June 2019

Zhang Y, Pan Z (2016) 网络贷款疯狂入侵大学校园是福是祸?[Promise or peril: online lending's aggressive invasion in college campus]. China Youth Daily http://zqb.cyol.com/html/2016-03/21/nw.D110000zgqnb_20160321_2-04.htm. Accessed 11 June 2019

Zhuo, S., 2019. 2018年银行存款市场:利率上升 竞争激烈 [Bank deposit market in 2018: rising interest rate, intense competition]. 中国金融新闻网[China financial news]. https://www.financialnews.com.cn/pl/ci/201901/t20190109_152646. html. Accessed 29 July 2020

\section{Publisher's Note}

Springer Nature remains neutral with regard to jurisdictional claims in published maps and institutional affiliations. 